\title{
Perbandingan Teknik Aerasi dan Ultrasonikasi Gelasi Ionik Nanopartikel Deksametason Natrium Fosfat
}

\section{Comparison of Aeration and Ultra-sonication Techniques for Ionic Gelation Nanoparticle Dexamethasone Sodium Phosphate}

\author{
Bambang Hernawan Nugroho ${ }^{1,2 *}$, Multi Tri Wardani, ${ }^{1}$ Suparmi ${ }^{1}$

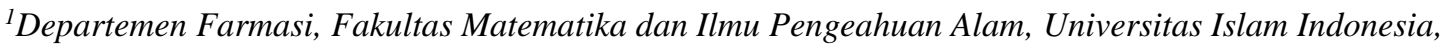 \\ Yogyakarta, Indonesia \\ ${ }^{2}$ Pusat Penelitian Nanofarmasi, Departemen Farmasi, FMIPA Universitas Islam Indonesia, Yogyakarta, \\ Indonesia \\ *Email: bambang.hernawan@uii.ac.id
}

Diterima: 29 Agustus 2019 Direvisi: 8 Mei $2020 \quad$ Disetujui: 21 Juni 2020

\begin{abstract}
Abstrak
Alginat, polimer alami yang biokompatibel dan biodegradabel, telah banyak digunakan sebagai pembawa molekul obat menggunakan metode gelasi ionik (crosslinking). Salah satu faktor yang harus diperhatikan dalam sintesisnya adalah efek mekanik. Tujuan penelitian ini adalah menjelaskan proses preparasi dan karakteristik dari crosslinker kalsium alginat pembawa deksametason natrium fosfat dengan teknik low energy dan high energy. Nanosuspensi dibuat dalam enam formula menggunakan 3 teknik, yaitu low energy (aerasi), high energy (ultrasonikasi), dan kombinasi low dan high energy (aerasi dan ultrasonikasi) dengan konsentrasi deksametason natrium fosfat dan natrium alginat yang tetap, yaitu $0,2 \%$ dan $0,1 \%$, serta dengan konsentrasi kalsium klorida $0,02 \%$ dan $0,2 \%$. Penentuan ukuran partikel, zeta potensial dan morfologi dari nanopartikel dilakukan menggunakan Particle Size Analyzer (PSA), Scanning Electron Microscope (SEM), dan Transmission Electron Microscope (TEM). Penetapan nilai efisiensi enkapsulasi dilakukan menggunakan spektrofotometer UV/Vis dan analisis statistika hasil nanosuspensi dilakukan menggunakan uji MANOVA. Sintesis nanosuspensi menggunakan teknik kombinasi low dan high energy (aerasi dan ultrasonikasi) menghasilkan karakteristik paling optimal dengan nilai ukuran partikel $352,90 \pm 6,10 \mathrm{~nm}$, indeks polidispersitas terhomogen $(0,52 \pm 0,04)$, zeta potensial optimal $-44,40 \pm 0,4 \mathrm{mV}$, efisiensi enkapsulasi $49,5-74,8 \%$ dan bentuk partikel yang sferis. Dapat disimpulkan bahwa preparasi crosslinker kalsium alginat sebagai pembawa DNF menggunakan teknik kombinasi low dan high energy merupakan metode preparasi yang menghasilkan nanosuspensi paling optimal.
\end{abstract}

Kata kunci: Alginat; Gelasi ionik; Deksametason natrium fosfat; Aerasi; Ultrasonikasi

\begin{abstract}
Alginate, a biocompatible and biodegradable natural polymer, has been widely used as a drug molecular carrier using ionic gelation methods (crosslinking). One of the factors that must be taken into account in its preparation is the mechanical effect. The purpose of this study was to explain the preparation process and the characteristics of the calcium alginate crosslinkers as dexamethasone sodium phosphate carriers with low energy and high energy techniques. Nanosuspension is made in six formulas using 3 techniques: low energy (aeration), high energy (ultrasonication), low and high energy (aeration and ultrasonication) with a fixed concentration of dexamethasone sodium phosphate and sodium alginate, that is $0,2 \%$ and $0,1 \%$, with $0,02 \%$ and $0,2 \%$ of calcium chloride. Determination of particle size, zeta potential, and morphology of nanoparticles using Particle Size Analyzer (PSA) and Scanning Electron Microscope (SEM), Transmission Electron Microscope (TEM). Determination of encapsulation efficiency using UV/Vis spectrophotometer and statistical analysis using MANOVA test. Synthesis of nanosuspension using a combination of low and high energy (aeration and ultrasonication) results in the most optimal characteristics with particle size value of $352.90 \pm 6.10 \mathrm{~nm}$, homogenized polydispersity index $(0,52 \pm 0,04)$, optimal potential zeta $-44,40 \pm 0,4 \mathrm{mV}$, the encapsulation efficiency of 49,5 - 74,8\% and spherical particle shape. It can be concluded that the preparation using a combination of low and high energy is the most optimal preparation result.
\end{abstract}

Keyword: Alginate; Ionic gelation; Dexamethasone sodium phosphate; Aeration; Ultrasonication 


\section{PENDAHULUAN}

Deksametason natrium fosfat (DNF) merupakan obat golongan kortikosteroid yang memiliki khasiat antiinflamasi kuat yang merupakan salah satu alternatif terapi pengobatan Inflammatory Bowel Disease (IBD) dengan waktu paruh pendek yaitu sekitar 2-3 jam. Pada kasus IBD, lapisan permukaan usus membentuk celah yang menciptakan potensi untuk memodifikasi karakteristik pelepasan obat dengan memasukkan partikel pembawa obat antiinflamasi yang berukuran lebih kecil. Partikel tersebut akan melekat di celah permukaan usus untuk pelepasan obat secara perlahan. Pemberian deksametason yang terenkapsulasi lebih efektif dalam pengobatan infeksi usus dibandingkan dengan deksametason kovensional. ${ }^{1,2}$

Gelasi ionik merupakan metode populer pilihan dalam sintesis ikatan sambung silang (crosslink) senyawa enkapsulator. Sodium alginat larut dalam air dan dapat disambungkan silang dengan adanya kation divalen atau polivalen seperti $\mathrm{Ca}^{2+}$ dan $\mathrm{Zn}^{2+}$. Sumber kalsium yang digunakan dalam penelitian ini adalah kalsium klorida. Kalsium klorida sangat banyak digunakan untuk pembentukan gel alginat. Kelarutan dalam air yang tinggi membuat kecepatan gelasinya tinggi. ${ }^{3-5}$

Penelitian sebelumnya telah menunjukkan bahwa teknik ultrasonikasi mampu digunakan untuk menyintesis ikatan silang kitosan-tripolifosfat sebagai pembawa DNF dengan homogenisasi menggunakan ultrasonikator. ${ }^{6}$ Penelitian lain membuktikan bahwa teknik stirring menggunakan magnetic stirrer dapat menyintesis ikatan silang kalsium alginat dengan berbagai variasi konsentrasi alginat. ${ }^{7}$ Studi ini berfokus pada efek mekanik yang perlu dipertimbangkan pemilihannya dalam sintesis suatu crosslinker. Efek mekanik pada proses homogenisasi dapat menimbulkan percepatan partikel, getaran, tekanan pancaran dan gaya gesek yang dimanfaatkan untuk mengecilkan ukuran suatu partikel dan menjaga partikel tetap kecil terhadap pengaruh pertumbuhan partikel dan aglomerasinya. ${ }^{6-10}$ Efek mekanik dapat dihasilkan melalui perputaran, getaran magnetic stirrer, dan pergerakan gelembung udara aerasi (teknik low energy), maupun dari getaran gelombang ultrasonik (utrasonikator/ teknik high energy).

Penulis sebelumnya telah melakukan penelitian yang membuktikan bahwa metode aerasi dapat digunakan untuk membentuk nanopartikel DNF dengan gelasi ionik kalsium alginat. Teknik aerasi yang digunakan dibandingkan dengan teknik ultrasonikasi yang sudah banyak terbukti mampu menghasilkan nanopartikel berkualitas. Tujuan dari penelitian ini adalah untuk menjelaskan proses preparasi dan karakteristik dari crosslinker kalsium alginat pembawa DNF yang dihasilkan melalui penggunaan teknik low energy (aerasi), high energy (ultrasonikasi), dan teknik kombinasi (aerasi dan ultrasonikasi) dalam proses pembentukan ukuran nanopartikel.

\section{METODE PENELITIAN}

\section{Alat dan Bahan}

Alat-alat yang digunakan meliputi Scanning Electron Microscope (Hitachi SU 3500), Transmission Electron Microscope (JEM 1400, JEOL), Spektrofotometer UV/Vis (UV-1800 Shimadzu), Dynamic Light Scattering (Horiba SZ 100), ultrasonic homogenizer probes (Model 150VT Biologics), dan syringe pump (SPLab02 Shenchen). Bahan-bahan yang digunakan antara lain aquabides dari laboratorium Teknologi Farmasi, deksametason natrium fosfat (Sanofi, 99,5\%), kalsium klorida (Merck), dan natrium alginat (Sigma-Aldrich).

\section{Preparasi nanopartikel}

Deksametason natrium fosfat (DNF) sebanyak $200 \mathrm{mg}$ dilarutkan ke dalam larutan natrium alginat $0,1 \%$ dalam botol vial dengan dihomogenisasi menggunakan ultrasonikator pada amplitudo $40 \%$ selama 1 menit sehingga terbentuk larutan DNFalginat. Selanjutnya, disiapkan tiga botol 
vial yang berisi $15 \mathrm{~mL}$ larutan DNF-alginat lalu masing-masing ditambahkan $10 \mathrm{~mL}$ larutan $\mathrm{CaCl}_{2}$ drop by drop dengan syring pump di bawah putaran pengadukan selama 2 menit hingga terbentuk suspensi. ${ }^{1,4,6}$ Penelitian ini menggunakan 2 variasi rasio natrium alginat dan $\mathrm{CaCl}_{2}$, yaitu (5:1) dan (1:2), sekaligus menggunakan 3 jenis pengaduk: aerator, ultrasonikator, dan kombinasi aerator-ultrasonikator. ${ }^{7,11,12}$

Tabel 1. Formula nanosuspensi DNF terjerap kalsium alginat

\begin{tabular}{ccccc}
\hline \multirow{2}{*}{ Formula } & \multicolumn{3}{c}{ Konsentrasi (\%) } & Teknik \\
\cline { 2 - 4 } & DNF & $\begin{array}{c}\text { Natrium } \\
\text { alginat }\end{array}$ & $\mathrm{CaCl}_{2}$ & \\
\hline a1 & 0,2 & 0,1 & 0,02 & Aerasi \\
a2 & 0,2 & 0,1 & 0,2 & Aerasi \\
b1 & 0,2 & 0,1 & 0,02 & Ultrasonikasi \\
b2 & 0,2 & 0,1 & 0,2 & Ultrasonikasi \\
c1 & 0,2 & 0,1 & 0,02 & $\begin{array}{c}\text { Aerasi dan } \\
\text { ultrasonikasi } \\
\text { c2 }\end{array}$ \\
\cline { 4 - 5 } & 0,2 & 0,1 & 0,2 & $\begin{array}{c}\text { Aerasi dan } \\
\text { ultrasonikasi }\end{array}$ \\
\hline
\end{tabular}

\section{Uji organoleptis}

Uji organoleptis pada penelitian ini meliputi pengamatan terhadap warna (kekeruhan) sediaan suspensi yang dihasilkan. ${ }^{4,6}$

\section{Analisis ukuran dan morfologi partikel}

Sediaan diambil $1 \mathrm{~mL}$ kemudian diencerkan ke dalam $5 \mathrm{~mL}$ aquabides kemudian diaduk perlahan hingga membentuk dispersi. Selanjutnya, diameter partikel dan zeta potensial diukur sebanyak 3 kali untuk masing-masing formula menggunakan alat Particle Size Analyzer dengan metode Dynamic Light Scattering. ${ }^{3,13}$

Morfologi nanopartikel DNF diperiksa menggunakan Scanning Electron Microscope, dan Transmission Electron Microscope. Larutan sampel suspensi nanopartikel diteteskan pada grid tembaga. Larutan yang telah meresap dan kering kemudian dilapisi dengan karbon, lalu dianalisis menggunakan SEM dan TEM sebanyak 3 kali percobaan. ${ }^{13,14}$

\section{Analisis efisiensi enkapsulasi}

Larutan stok DNF dibuat dengan konsentrasi $100 \mu \mathrm{g} / \mathrm{ml}$ kemudian diencerkan untuk membuat larutan standar DNF $10 \mu \mathrm{g} / \mathrm{ml}$. Selanjutnya, larutan standar digunakan untuk menentukan panjang gelombang maksimum larutan menggunakan spektrofotometer UV-Vis pada rentang panjang gelombang 200-400 nm. Kurva kalibrasi larutan DNF ditentukan dengan mengukur serapan larutan standar berkonsentrasi $10 \mu \mathrm{g} / \mathrm{ml}$, $15 \mu \mathrm{g} / \mathrm{ml}, 20 \mu \mathrm{g} / \mathrm{ml}, 25 \mu \mathrm{g} / \mathrm{ml}$, dan 30 $\mu \mathrm{g} / \mathrm{ml}$.

Perhitungan efisiensi enkapsulasi dilakukan dengan mengambil sebanyak 7 $\mathrm{mL}$ sampel yang dimasukkan ke dalam tabung vivaspin $(300 \mathrm{kD}$ WMCO $)$, disentrifugasi pada $2000 \mathrm{rpm}$ selama 1 jam, lalu diambil supernatan dan diukur jumlah deksametason natrium fosfat yang tidak terjerap dalam nanopartikel. Penetapan kadarnya dilakukan menggunakan spektrofotometer UV-Vis yang selanjutnya dihitung memakai persamaan berikut: ${ }^{4,15,16}$

$$
\mathrm{EE} \%=\frac{\mathrm{DNF}_{\mathrm{T}}-\mathrm{DNF}_{\mathrm{b}}}{\mathrm{DNF}_{\mathrm{T}}} \times 100 \%
$$

Keterangan:

$\mathrm{EE}=$ efisiensi enkapsulasi

$\mathrm{DNF}_{\mathrm{T}}=$ jumlah deksametason natrium fosfat

$\mathrm{DNF}_{\mathrm{b}}=$ jumlah deksametason natrium fosfat yang bebas.

\section{Analisis statistika}

Hasil pembacaan ukuran partikel, indeks polidispersitas (polydiperity index, PDI), zeta potensial, dan efisiensi enkapsulasi dari masing-masing formula dianalisis menggunakan MANOVA untuk mengetahui perbedaan bermakna dari pengaruh teknik formulasi yang digunakan. 


\section{HASIL DAN PEMBAHASAN}

\section{Pengaruh variasi teknik formulasi terhadap organoleptis nanosuspensi DNF}

Variasi teknik formulasi (low dan high energy) yang digunakan memberikan perbedaan hasil kejernihan dan viskositas dari suspensi yang dihasilkan. Sugita, dkk melaporkan bahwa percepatan partikel, getaran, tekanan pancaran dan gaya gesek yang cepat dari teknik formulasi akan membentuk nanosuspensi. ${ }^{6}$ Aerator (formula a1 dan a2) yang digunakan dalam teknik low energy menimbulkan getaran kecil pada partikel melalui gerakan dan perputaran dari gelembung udara. Teknik high energy (formula b1 dan b2) yang memanfaatkan gelombang ultrasonik akan mengakibatkan getaran partikel yang sangat besar di dalam medium. Kombinasi dari kedua teknik (formula c1 dan c2) memberikan energi/getaran yang optimal sehingga menghasilkan nanosuspensi paling jernih karena kestabilan dan ukuran partikelnya.

Kejernihan juga dipengaruhi oleh konsentrasi $\mathrm{CaCl}_{2}$. Pada konsentrasi rendah $(0,02 \%)$, partikel yang terbentuk tidak terlihat secara kasat mata karena dihasilkan sistem koloid yang memiliki partikel sangat halus seperti yang dipaparkan oleh Toscano, dkk. ${ }^{9}$ Akan tetapi, pada konsentrasi $\mathrm{CaCl}_{2}$ tinggi $(0,2 \%)$ diperoleh larutan yang sedikit keruh dan viskositas yang hampir seperti gel. Dari keenam formula yang dibuat, formula c1 dengan teknik kombinasi dan konsentrasi $\mathrm{CaCl}_{2}$ $0,02 \%$ merupakan sediaan nanosuspensi terbaik dari segi organoleptis (Gambar 1).

\section{Pengaruh variasi teknik formulasi terhadap ukuran partikel nanosuspensi DNF}

Finotelli, dkk memaparkan bahwa ukuran partikel yang kecil sangat dipengaruhi oleh percepatan partikel, getaran, tekanan pancaran, dan gaya gesek yang cepat dari teknik formulasi yang digunakan. $^{7}$ Faktor penting dalam karakterisasi dan evaluasi dari sistem nanopartikel yaitu ukuran dan distribusi ukuran partikel yang ditetapkan menggunakan alat Particle Size Analyzer (PSA) metode Dynamic Light Scattering (DLS).

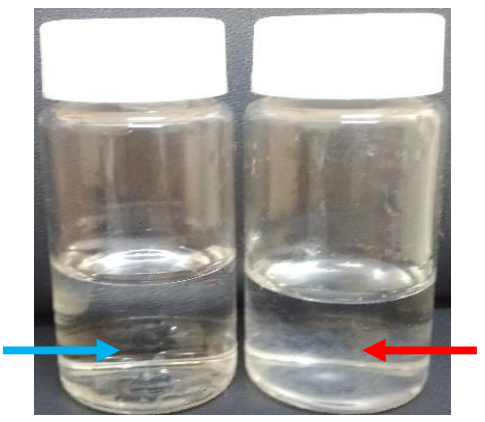

(a1) (a2)

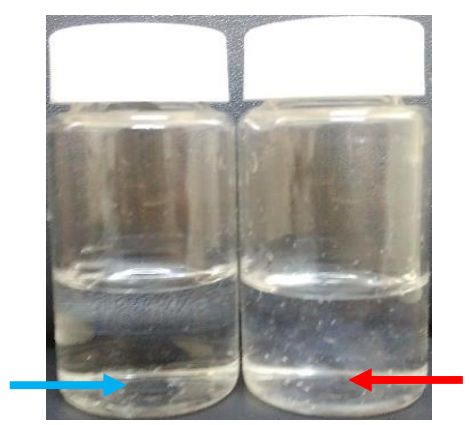

(b1)

(b2)

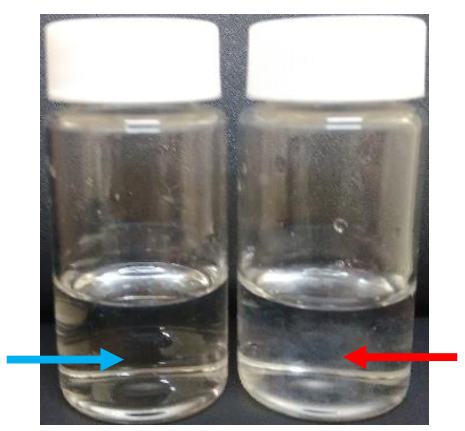

(c1)

(c2)

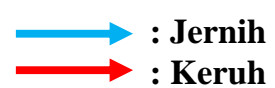

Gambar 1. Hasil preparasi nanosuspensi kalsium alginat pembawa DNF dengan variasi konsentrasi $\mathrm{CaCl}_{2}$ (1) $0,02 \%$ dan (2) $0,2 \%$ menggunakan teknik (a) aerasi, (b) ultrasonikasi, dan (c) aerasi dan ultrasonikasi

Suatu formula sudah dapat dikatakan sebagai sistem nanopartikel jika memiliki ukuran partikel dalam kisaran 1-1000 nm. ${ }^{2,3,17}$ Formula-formula yang dihasilkan sebagian besar telah memenuhi syarat ukuran yang bisa menembus jaringan epitel pada usus, yaitu berukuran di bawah $500 \mathrm{~nm}$. Semakin kecil ukuran partikel maka semakin cepat obat masuk ke dalam jaringan untuk dapat bekerja. ${ }^{2}$ Teknik dan 
konsentrasi $\mathrm{CaCl}_{2}$ yang ditambahkan pada formula dapat berpengaruh terhadap karakteristik nanopartikel yang dihasilkan. Teknik yang menggunakan aerasi (low energy), teknik dengan percepatan partikel, getaran, dan gaya gesek kecil menghasilkan ukuran partikel yang lebih besar daripada teknik ultrasonikasi (high energy). Konsentrasi $\mathrm{CaCl}_{2}$ berpengaruh terhadap muatan nanopartikel dari ikatan antara $\mathrm{Ca}^{2+}$ dengan anion alginat yang terbentuk dan nilai zeta potensial. Karakteristik sediaan hasil formula berdasarkan parameter fisik dapat dilihat pada Tabel 2.

Tabel 2. Karakteristik nanopartikel berdasarkan teknik formulasi nanopartikel DNF

\begin{tabular}{|c|c|c|c|c|}
\hline \multirow{2}{*}{$\begin{array}{c}\text { Parameter } \\
\text { Uji }\end{array}$} & \multirow{2}{*}{$\begin{array}{c}\mathrm{CaCl}_{2} \\
(\%)\end{array}$} & \multicolumn{3}{|c|}{ Teknik Formulasi } \\
\hline & & Aerasi & $\begin{array}{l}\text { Ultra- } \\
\text { sonik }\end{array}$ & Gabungan \\
\hline \multirow{2}{*}{ Warna } & 0,02 & $\begin{array}{c}\text { Sedikit } \\
\text { keruh }\end{array}$ & $\begin{array}{c}\text { Sedikit } \\
\text { keruh }\end{array}$ & Bening \\
\hline & 0,2 & $\begin{array}{l}\text { Sedikit } \\
\text { keruh }\end{array}$ & $\begin{array}{l}\text { Sedikit } \\
\text { keruh }\end{array}$ & $\begin{array}{l}\text { Sedikit } \\
\text { keruh }\end{array}$ \\
\hline \multirow{2}{*}{$\mathrm{pH}$} & 0,02 & 7,47 & 7,36 & 7,34 \\
\hline & 0,2 & 7,34 & 7,33 & 7,36 \\
\hline \multirow{2}{*}{$\begin{array}{c}\text { Ukuran } \\
\text { partikel } \\
(\mathrm{nm})\end{array}$} & 0,02 & $\begin{array}{c}441,53 \pm \\
92,69\end{array}$ & $\begin{array}{c}401,27 \pm \\
41,05\end{array}$ & $\begin{array}{c}352,90 \pm \\
6,10\end{array}$ \\
\hline & 0,2 & $\begin{array}{c}1327,47 \pm \\
635,99\end{array}$ & $\begin{array}{c}1119,33 \pm \\
179,19\end{array}$ & $\begin{array}{c}1103,27 \pm \\
37,12\end{array}$ \\
\hline \multirow{2}{*}{ PDI } & 0,02 & $\begin{array}{c}0,51 \pm \\
0,09\end{array}$ & $\begin{array}{c}0,53 \pm \\
0,04\end{array}$ & $0,52 \pm 0,04$ \\
\hline & 0,2 & $\begin{array}{c}0,44 \pm \\
0,38\end{array}$ & $\begin{array}{c}0,46 \pm \\
0,17\end{array}$ & $0,50 \pm 0,15$ \\
\hline \multirow{2}{*}{$\begin{array}{c}\text { Zeta } \\
\text { potensial } \\
(\mathrm{mV})\end{array}$} & 0,02 & $\begin{array}{c}-58,10 \pm \\
0,66\end{array}$ & $\begin{array}{c}-61,40 \pm \\
0,36\end{array}$ & $\begin{array}{c}-44,40 \pm \\
0,4\end{array}$ \\
\hline & 0,2 & $\begin{array}{c}-19,73 \pm \\
0,12\end{array}$ & $\begin{array}{c}-11,70 \pm \\
0,36\end{array}$ & $\begin{array}{c}-14,70 \pm \\
0,10\end{array}$ \\
\hline
\end{tabular}

Formula $\mathrm{CaCl}_{2} \quad 0,02 \%$ menggunakan teknik aerasi dan ultrasonikasi memiliki ukuran partikel terkecil $(352,90 \pm 6,10 \mathrm{~nm})$ dan polidispersitas atau homogenitas ukuran partikel terbaik yang ditandai dengan masing-masing hanya memunculkan satu puncak sempit dan tinggi, yaitu berturut-turut berkisar di antara 100-500 nm (Gambar 2).

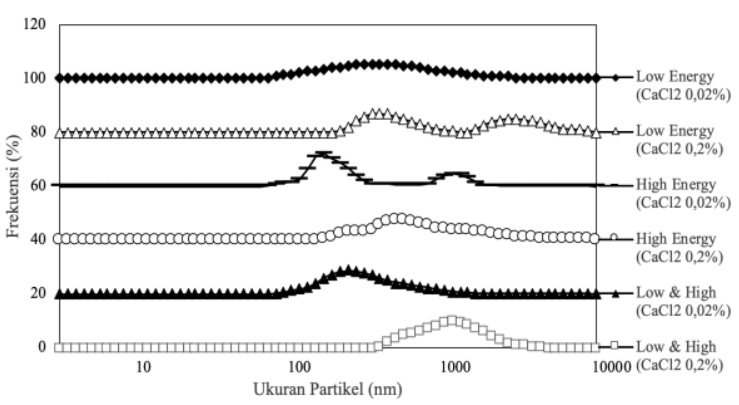

Gambar 2. Pengaruh penggunaan teknik low dan high energy terhadap ukuran partikel nanosuspensi DNF.

Variasi konsentrasi $\mathrm{CaCl}_{2}$ memberi pengaruh besar terhadap ukuran partikel nanosuspensi yang dihasilkan (Gambar 3). Konsentrasi kalsium klorida yang rendah mampu menghasilkan ukuran partikel berukuran nanometer karena pertumbuhan dan aglomerasi partikel rendah. Ini sesuai dengan hasil penelitian Khakim dan Atun bahwa penggunaan $\mathrm{CaCl}_{2}$ dengan konsentrasi tinggi menyebabkan terlalu banyak ikatan antara $\mathrm{Ca}^{2+}$ dengan anion alginat yang terbentuk. Ikatan tersebut menyebabkan terbentuknya padatan terlarut sehingga apabila terlalu banyak akan menyebabkan ukuran partikel padatan semakin besar. ${ }^{12}$

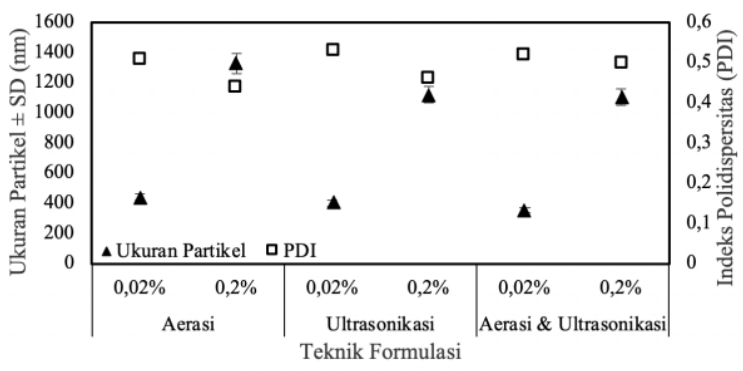

Gambar 3. Pengaruh teknik formulasi terhadap ukuran partikel dan indeks polidispersitas nanosuspensi, variasi konsentrasi $\mathrm{CaCl}_{2}$ berpengaruh terhadap ukuran dan distribusi partikel.

Nilai distribusi dan keseragaman ukuran partikel nano dapat dilihat menggunakan indeks polidispersitas (polydispersity index, PDI). Nilai indeks polidispersi yang baik berada dalam dalam rentang $<0,7$.

Muatan pada permukaan suatu partikel dan kestabilan dari sediaan yang telah dibuat bisa dilihat melalui pengukuran 
zeta potensial pada sistem koloid. Hasil pengukuran terhadap preparasi nanosuspensi yang telah dibuat menunjukkan bahwa muatan permukaan partikel adalah negatif (Gambar 4).

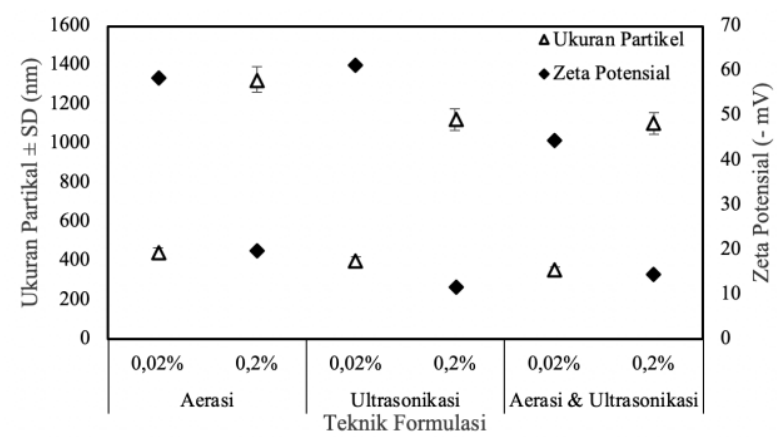

Gambar 2. Pengaruh teknik formulasi terhadap ukuran partikel dan zeta potensial nanosuspensi, konsentrasi $\mathrm{CaCl}_{2}$ yang ditambahkan menurunkan nilai zeta potensial.

Sistem koloid dinyatakan stabil bila muatannya lebih dari +/- $30 \mathrm{mV}$. Dari beberapa formula yang dihasilkan, diketahui bahwa perbedaan teknik formulasi dan konsentrasi $\mathrm{CaCl}_{2}$ memberikan pengaruh terhadap nilai zeta potensial seperti penjelasan Dhanka dkk. ${ }^{4}$ Konsentrasi $\mathrm{CaCl}_{2}$ menurunkan nilai zeta potensial. Turunnya nilai zeta potensial mengakibatkan nanopartikel memilki kecenderungan mengalami agregasi. Sementara itu, muatan tinggi akan mencegah terjadinya agregasi karena partikel saling tolak menolak satu sama lain. Formula c1 memiliki nilai zeta potensial 44,40 $\pm 0,4 \mathrm{mV}$. Hal ini menunjukkan bahwa sediaan tersebut akan stabil karena memiliki zeta potensial yang mendekati $+/-30 \mathrm{mV}$.

Tabel 3. Hasil analisis statistik pengaruh teknik formulasi terhadap karakteristik nanosuspensi menggunakan uji MANOVA

\begin{tabular}{|c|c|c|c|c|c|c|c|}
\hline & & & & & E & & \\
\hline & urce & $\begin{array}{l}\text { Type III } \\
\text { Sum of }\end{array}$ & df & Mean & F & Sig. & $\begin{array}{c}\text { Partial } \\
\text { Eta }\end{array}$ \\
\hline & $\begin{array}{l}\text { Udkuran } \\
\text { Partikel }\end{array}$ & 11816,607 & 2 & 5908,303 & 1,719 & 0,257 & 0,364 \\
\hline & PDI & 0,001 & 2 & 0,000 & 0,078 & 0,926 & 0,025 \\
\hline ర్ల & $\begin{array}{l}\text { Zeta } \\
\text { Potensial }\end{array}$ & 494,402 & 2 & 247,201 & 984,429 & 0,000 & 0,997 \\
\hline & $\%$ EE & 7,813 & 2 & 3,907 & 9542,094 & 0,000 & 1,000 \\
\hline & $\begin{array}{l}\text { Ukuran } \\
\text { Partikel }\end{array}$ & 93843,262 & 2 & 46921,631 & 0,321 & 0,737 & 0,097 \\
\hline 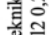 & PDI & 0,006 & 2 & 0,003 & 0,047 & 0,954 & 0,015 \\
\hline$\stackrel{\Xi}{\tilde{U}}$ & $\begin{array}{c}\text { Zeta } \\
\text { Potensial }\end{array}$ & 98,000 & 2 & 49,000 & 980,000 & 0,000 & 0,997 \\
\hline & $\%$ EE & 159,783 & 2 & 79,892 & 1990377,244 & 0,000 & 1,000 \\
\hline
\end{tabular}

Analisis statistik MANOVA dilakukan karena 1 variabel dependen berupa karakteristik nanosuspensi yang dipengaruhi teknik formulasi, dihubungkan dengan 4 variabel independen, yaitu ukuran partikel, indeks polidispersitas, zeta potensial, dan efisiensi enkapsulasi. Hasil analisis statistik menunjukkan bahwa teknik formulasi memberikan pengaruh secara signifikan terhadap ukuran partikel, PDI, nilai zeta potensial dan efisiensi enkapsulasi (\%EE) nanosuspensi (Tabel $3)$.

\section{Pengaruh variasi teknik formulasi pada morfologi nanosuspensi DNF}

SEM dan TEM adalah alat yang dapat digunakan untuk melihat hasil enkapsulasi crosslinker dan menentukan bagaimana bentuk struktur dan morfologi suatu nanopartikel. Untuk uji morfologi ini hanya satu formula yang dianalisis yaitu formula dengan konsentrasi $\mathrm{CaCl}_{2}, 0,02 \%$ yang menggunakan teknik kombinasi low dan high energy karena dinilai sebagai formula yang paling optimal di antara formula yang lain ditinjau dari ukuran partikel, distribusi ukuran partikel dan zeta potensialnya.

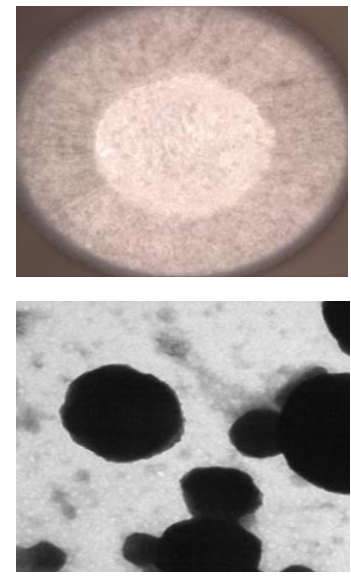

Gambar 5. a) Lapisan enkapsulasi yang menyalut DNF terlihat dengan SEM perbesaran 10.000×; (b) Bentuk nanosuspensi hasil analisis menggunakan TEM 500x

Hasil analisis morfologi nanosuspensi menunjukkan bahwa pada nanopartikel yang dihasilkan terdapat lapisan enkapsulasi yang menyelubungi DNF dan 
berbentuk sferis yang hampir bulat (Gambar 5), meskipun ada sebagian partikel yang masih bergabung. Ini disebabkan formula dengan konsentrasi $\mathrm{CaCl}_{2}$ 0,02\% dengan teknik kombinasi low dan high energy memiliki nilai zeta potensial tinggi sehingga menurunkan potensi agregasi dengan tingginya tolakan antarpartikel. Partikel yang memiliki bentuk sferis lebih disukai karena akan mempertahankan obat yang dibawa. ${ }^{4,12,14}$

\section{Pengaruh variasi teknik formulasi terhadap nilai efisiensi enkapsulasi nanosuspensi DNF}

Analisis efisiensi enkapsulasi dilakukan menggunakan spektrofotometer UV/Vis. Deksametason natrium fosfat memiliki gugus kromofor dan auksokrom yaitu gugus benzene dan gugus $\mathrm{C}=\mathrm{O}$ yang dapat terdeteksi pada panjang gelombang maksimal 241,3 nm. Pada tahap ini dibuat kurva baku mulai dari 10 ppm hingga 30 ppm. Dari kurva tersebut diperoleh persamaan garis $\mathrm{y}=0,0294 \mathrm{x}-0,0414$ dengan nilai $\mathrm{r}^{2}=0,9998$. Persamaan ini digunakan untuk menentukan jumlah deksametason natrium fosfat yang terjerap di dalam crosslinker kalsium alginat. Efisiensi enkapsulasi dilakukan dengan metode ultrafiltrasi mengunakan membran dengan nilai molecular weight cutoff 300 kilodalton.

Efisiensi enkapsulasi penting untuk dilakukan terutama dalam sistem penghantaran obat karena nilainya bisa menggambarkan kemampuan crosslinker dalam membawa bahan aktif menuju target sasaran terapi. ${ }^{4,15,16}$

Keseluruhan formula memiliki efisiensi enkapsulasi tidak berbeda jauh. Hal ini dikarenakan efisiensi enkapsulasi suatu partikel bergantung pada sifat kelarutan obat di dalam matriks atau polimernya, selain itu juga dipengaruhi oleh jumlah polimer yang digunakan pada tiap formula. ${ }^{9}$ Deksametason natrium fosfat yang digunakan mudah larut di dalam polimer natrium alginat sehingga obat terjerap kuat dalam polimer/matriks. Formula c2 menjadi nanosuspensi dengan
\%EE tertinggi dikarenakan konsentrasi $\mathrm{CaCl}_{2}$ yang tinggi $(0,2 \%)$ dan menggunakan teknik formulasi kombinasi yang optimal (Tabel 4).

Tabel 4. Hasil penentuan efisiensi enkapsulasi nanopartikel

\begin{tabular}{ccccc}
\hline & & \multicolumn{3}{c}{ Teknik Formulasi } \\
\cline { 3 - 5 } Hasil & $\begin{array}{c}\mathrm{CaCl}_{2} \\
(\%)\end{array}$ & $\begin{array}{c}\text { Low } \\
\text { Energy }\end{array}$ & $\begin{array}{c}\text { High } \\
\text { Energy }\end{array}$ & $\begin{array}{c}\text { Low } \\
\text { dan } \\
\text { High } \\
\text { Energy }\end{array}$ \\
\hline \multirow{2}{*}{$\% \mathrm{EE}$} & 0,02 & 49,8 & 47,7 & 49,5 \\
& 0,2 & 66,8 & 65,1 & 74,8 \\
\hline
\end{tabular}

\section{KESIMPULAN}

Berdasarkan penelitian yang dilakukan dan hasil yang diperoleh maka dapat disimpulkan bahwa sintesis nanosuspensi kalsium alginat pembawa deksametason natrium fosfat menggunakan metode gelasi ionik dengan teknik kombinasi low dan high energy pada konsentrasi $\mathrm{CaCl}_{2}$ $0,02 \%$ menghasilkan formula paling optimal ditinjau dari beberapa karakteristik nanopartikel yang telah diperoleh.

\section{UCAPAN TERIMA KASIH}

Penulis mengucapkan terima kasih kepada Jurusan Farmasi dan Pusat Penelitian Nanofarmasi Universitas Islam Indonesia yang sudah menunjang sarana dan prasarana dalam penelitian ini.

\section{DAFTAR RUJUKAN}

1. Dubnika A, Loca D, Berzina-Cimdina L. Cross-linked dexamethasone sodium phosphate delivery systems based on silver doped hydroxyapatite scaffolds. Key Engineering Material. 2016;721:192-6.

2. Giron F, Pastó A, Tasciotti E, Abraham BP. Nanotechnology in the treatment of inflammatory bowel disease. Inflammatory Bowel Diseases. 2019;25(12):1871-80.

3. Bhatia S. Nanoparticles types, classification, characterization, fabrication methods and drug delivery applications. In: Natural Polymer Drug 
Delivery Systems. Springer, Cham; 2016. p. 33-93.

4. Dhanka M, Shetty C, Srivastava R. Methotrexate loaded alginate microparticles and effect of $\mathrm{Ca} 2+$ postcrosslinking: An in vitro physicochemical and biological evaluation. International Journal of Biological Macromolecules. 2010;110:294-307.

5. Hecht H, Srebnik S. Structural characterization of sodium alginate and calcium alginate. Biomacromolecules. 2016;17(6):2160-7.

6. Sugita P, Ambarsari L, Lidiniyah. Optimization of ketoprofen-loaded chitosan nanoparticle ultrasonication process. Procedia Chemistry. 2015;16:673-80.

7. Finotelli PV, Da Silva D, Sola-Penna M, Rossi AM, Farina M, Andrade LR, et al. Microcapsules of alginate/chitosan containing magnetic nanoparticles for controlled release of insulin. Colloids and Surfaces B: Biointerfaces. 2010;81(1):206-11.

8. Reddy A, Majumder AB. Use of a combined technology of ultrasonication, three-phase partitioning, and aqueous enzymatic oil extraction for the extraction of oil from Spirogyra sp. Journal of Engineering. 2016;2014(November 2014).

9. Toscano L, Montero G, Stoytcheva M, Cervantes L, Gochev V. Comparison of the performances of four hydrophilic polymers as supports for lipase immobilisation. Biotechnology \& Biotechnological Equipment. 2014;28(1):52-60.

10. Zhu X, Liu Y, Zhou C, Zhang S, Chen J. Novel and high-performance magnetic carbon composite prepared from waste hydrochar for dye removal. ACS Sustainable Chemistry \& Engineering [Internet]. 2014;2(4):969-77. Available from:

https://pubs.acs.org/doi/pdf/10.1021/sc4 $00547 \mathrm{y}$

11. Tyagi LK, Shekhar R, Gaur K, Kori ML. Development and in-vitro characterization of Ca-alginate beads of oxytetracycline hydrochloride for oral use: effect of process variables. American Journal of Pharmacological Sciences. 2017;5(3):63-70.
12. Khakim AN, Atun S. Pembuatan nanopartikel ekstrak kunci pepet (Kaempferia rotunda) dengan alginat pada berbagai variasi konsentrasi ion kalsium. Jurnal Kimia Dasar. 2017;6(1):43-51.

13. Saberi AH, McClements DJ. Effect of glycerol on formation, stability, and properties of vitamin-E enriched nanoemulsions produced using spontaneous emulsification. Journal of Colloid and Interface Science. 2013;411:105-13.

14. Kaur K. Formulation and evaluation of metformin hydrochloride microsphere by ionotropic gelation technique [Internet]. Thapar University; 2013. Available from: https://pdfs.semanticscholar.org/d972/ 722dd9217349e6a78dc805a87d3264e5 857d.pdf

15. Patel HM, Patel BB, Shah CN. Nanosuspension: A novel approch to enhance solubility of poorly water soluble drugs - A review. International Journal of Advances in Pharmaceutics. 2019;5(2):21-9.

16. Kalepu S, Nekkanti V. Improved delivery of poorly soluble compounds using nanoparticle technology: a review. Drug Delivery and Translational Research. 2016;6:319_ 32.

17. Shreya A, Raut SY, Managuli RS, Udupa N, Mutalik S. Active Targeting of drugs and bioactive molecules via oral administration by ligandconjugated lipidic nanocarriers: Recent advances. AAPS PharmSciTech. 2019;20(15). 